\title{
Explicit Competence, Implicit Competence, and Job Performance: The Analysis of Car Salespeople in Taiwan
}

\author{
Shin Tien Chen ${ }^{1}$ \\ ${ }^{1}$ Department of Business Management, Ming Chi University of Technology, Taiwan \\ Correspondence: Shin Tien Chen, Professor, Department of Business Management, Ming Chi University of \\ Technology, Taiwan. E-mail: cst490918@gmail.com
}

Received: June 28, 2015

Accepted: August 3, 2015

Online Published: August 17, 2015

doi:10.5430/jms.v6n3p50

URL: http://dx.doi.org/10.5430/jms.v6n3p50

\begin{abstract}
Car salesmanship is challenging. Fresh college graduates are keen to take on this challenge because of the financial rewards. This paper explores the skillsets required for an auto salesperson to stand out from the crowd by conducting a questionnaire survey on the salespeople in Nissan, Toyota, Honda, Ford and Mitsubishi in Taiwan. A total of 223 effective questionnaires are included in the study. The demographic factors such as sex and age are controlled, as well as the tenure, annual revenue, education background, locations and job titles of the salespeople, so as to highlight the relationship between sales and explicit competences and between sales and implicit competences. The empirical findings suggest that (1) explicit competence: the stronger the product competence and interpersonal skills of salespeople, the better the sales. Sale competence and Job performance are not significantly correlated. (2) There is no significant correlation between implicit competences and sales generated. (3) The implicit competence of salespeople reinforces the positive effect of product knowledge, interpersonal skills and sales techniques on sales.
\end{abstract}

Keywords: explicit competence, implicit competence, sale performance

\section{Introduction}

Successful product sale relies on the delivery of messages from salespeople (Howland, 1978; Peterson, Wright, and Weitz, 1984). A good salesperson has to be equipped with product knowhow, communication skills and the ability to listen to customers, articulate pros and cons of the product. Schermerhorn (1989) indicates that work performance is the product of competences, support and efforts. Spencer and Spencer (1993) argue that implicit competences (e.g. motivations, qualities, self-identification) and explicit competences (e.g. knowledge and technical ability) are both essential. They posit that $80 \%$ of the work performance stem from implicit competences and the remaining $20 \%$ from explicit competences. This paper believes that Schermerhorn and Spencer and Spencer seek to emphasize the multiplicative effects of explicit competences and implicit competences in job performance. According to Churchill (1985) and Erika (1999), explicit competences of a successful salesperson are by all means important, but implicit competences can often make up the insufficiency of explicit ones. It is worth noting that implicit competences are harder to develop and nurture compared to explicit competences (Milkovich and Newman, 1999; Mayer, 2003; Blank, 2008). Therefore, it can be inferred that a successful salesperson rely on the level of his/her implicit competences, although such competences cannot be easily trained.

Spencer and Spencer (1993) indicate that work performance of salespeople is based on threshold skillsets (knowledge and basic skills) and discretionary skillsets (achievement orientation and ambition). Milkovich and Newman (1999) extends on the basis of Spencer and Spencer (1993) by pointing out that 20\% of work performance by sales personnel comes from relevant knowledge and skills, explicit and observable. Such competences can be easily trained and developed. Meanwhile, $80 \%$ of work performance is built upon personality traits (such as ambition and drive for achievements), implicit and not easily trained or nurtured (Ulrich et al., 1995; Mirabile, 1997; Gendolla, 2006; Heilmann, 2011).

As previously stated, the majority of existing literature supports that the performance of sales personnel depends on both explicit and implicit competences. In fact, implicit competences have more impact than explicit ones. How do they interact with each other? This paper builds on the previous conclusions that work performance is underpinned by both explicit and implicit competences, although implicit competences are the key issue. Therefore, this paper sets out to examine whether implicit competences of auto sales staff reinforce the impact of explicit competences on job 
performance.

\section{Literature Review and Hypotheses}

\subsection{Theoretic Foundation}

The competences of salespeople can be classified into explicit and implicit. The majority of past studies confirm the influence of job competences on work performance (Spencer and Spencer, 1993; Arthey and Orth, 1999; Kim and Hong, 2005; Levenson, Vander Stede, and Cohen, 2006). This paper supports the views of Spencer and Spencer (1993) and Milkovich and Newman (1999) that the performance of sales staff hinges on the synergy of explicit and implicit competences and their impacts of job performance are complementary. The stronger the explicit competences (such as sales techniques, interpersonal skills and product knowledge), the better the sales generated by the salespeople. That said, this paper argues that the combination of strong implicit competences can create even better sales.

In other words, a certain level of explicit competences is prerequisite of any sales person. However, this paper does not expect a salesperson with strong explicit competences but weak implicit competences can generate good business. In contrast, a salesperson equipped with strong implicit competences but relatively weak explicit competences are still likely to generate good business. According to the core and surface competences described by Broeck et al. (2010), motivations and qualities are the key to job performances. The motivations and qualities they refer to and the motivation for achievements, self-drive, proactive-ness, ambition and aspirations described in this paper are basically the same things.

This paper posits that the sales generated by auto salespeople are the multiplication effects of explicit competences and implicit competences. Generally speaking, the strength of explicit competences affect the level of sales performances with some variables controlled. However, sales performances can be further improved when combined with better implicit competences (Vazirani, 2010). This paper examines whether implicit competences of auto sales personnel can reinforce the impact of explicit competences on sales performance. Figure 1 illustrates the research framework.

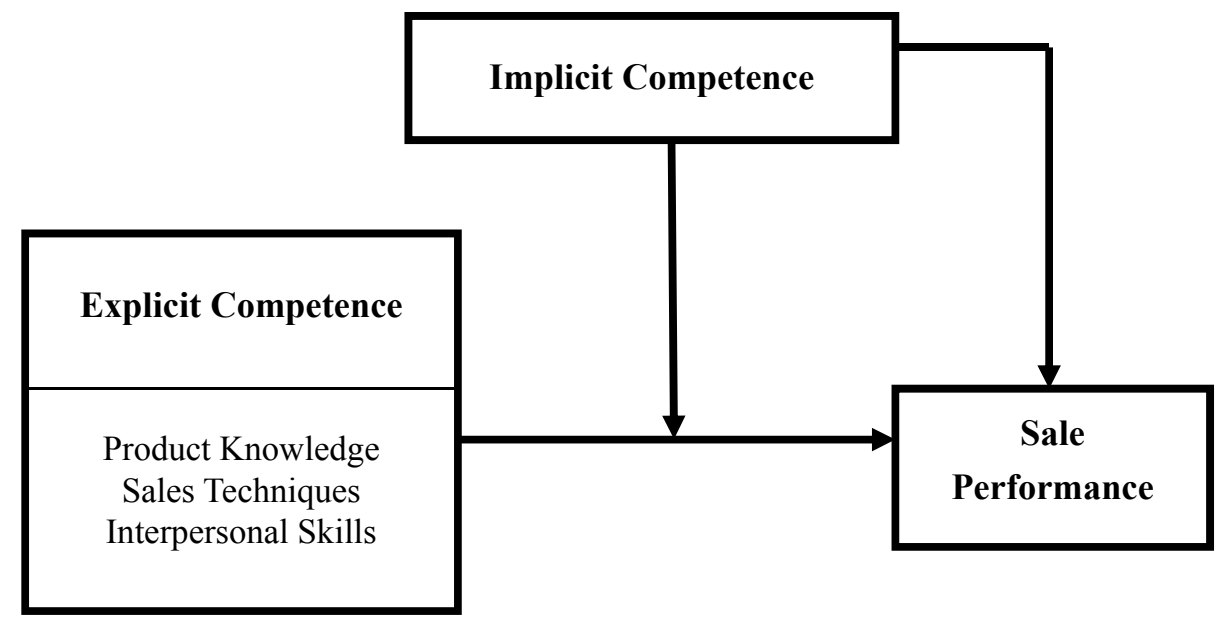

Figure 1. Research framework

\subsection{Research Hypotheses}

- Effect of Explicit Competences to Sale Performance

Explicit competences consist of three skillets, i.e. product knowledge, sales techniques and interpersonal skills.

Competences are a valuable ability for any individual (Dubois, Rothwell, Stern and Kemp, 2004; Wei and Lau, 2005; Seal, Boyatzis and Bailey, 2006). The skillsets and sale performance for sales personnel are interactive and influencing each other. Many studies suggest that explicit competences can improve sale performances (Spencer and Spencer, 1993; Arthey and Orth, 1999; Kim and Hong, 2005; Levenson, Vander stede, and Cohen, 2006).

This paper argues that product knowledge can be acquired. The better the product knowledge, the more information 
available to customers and the easier for sales people to complete transactions. Sales techniques can accelerate the selling process. The importance of interpersonal skills is evidenced by the positive correlation of interpersonal relations and sales (De Houwer, 2006; Nosek, 2007; Nosek and Smyth, 2007). Hence, this paper develops the following hypotheses:

H1a: The stronger the product knowledge, the higher revenue the salespeople can generate.

$\mathrm{H} 1 \mathrm{~b}$ : The better the sale technique, the higher revenue the salespeople can generate.

H1c: The stronger the interpersonal skills, the higher revenue the salespeople can generate.

- $\quad$ Effects of Implicit Competences on Sales Performance

Implicit competences refer to an individual's drive for achievement. A high achiever tends to generate better sales (Erika, 1999; Shaw, 2007). This paper believes that ambitious salespeople are better in dealing with stress and do not give up easily. The stronger the implicit competences, the less likely the salespeople throw in the towel and the more likely they are able to generate good business.

$\mathrm{H} 2$ : The stronger the implicit competences, the higher revenue the salespeople can generate.

- $\quad$ Explicit Competences, Implicit Competences and Sale Performance

Many scholars acknowledge the strong correlation between sale performance and competences (Becker, Huselid and Ulrich, 2001; Draganidis and Mentzas, 2006; Andrew and Johnson, 2006; Edwin, 2008). Explicit competences can mostly be acquired, but it is not the case with implicit competences. It is, nonetheless, possible to develop implicit competences via consultation and stress tests. According to Spencer and Spencer (1993), explicit competences only account for $20 \%$ of the competence model whilst implicit competences account for $80 \%$. Cofsky (1993) and Soderquist et al. (2010) also suggest that good performances are built upon strong implicit competences.

As stated above, salespeople should have a certain level of explicit competences. However, their performance seems to hinge on the level of implicit competences. This paper posits that weak implicit competences on top of strong explicit competences may not necessarily result in good sales performances. In contrast, strong implicit competences complementary to weak explicit competences can still boost sales performances. This paper develops the following hypotheses:

H3a: The implicit competences of salespeople can augment the positive effects of product knowledge on sales performances.

H3b: The implicit competences of salespeople can augment the positive effects of sales techniques on sales performances.

H3c: The implicit competences of salespeople can augment the positive effects of interpersonal skills on sales performances.

\section{Methodology}

\subsection{Variable Measurements}

This paper conducts a questionnaire survey to measure variables. The questions are developed mainly by reference to literature. Variables are measured with Likert Scale (of five), from "strongly agree" (5 points), "agree" (4 points), "neutral" ( 3 points), "disagree" ( 2 points) to "strongly disagree" (1 point). The higher the score, the stronger the agreement it is.

\section{- Explicit Competences}

Explicit competences consist of three skillets, i.e. product knowledge, sales techniques and interpersonal skills. The measurement is based on the core competence assessment for salespeople developed by Yildirim (2007). Table 1 summarizes the questions for individual competence. 
Table 1. Questionnaire for explicit competences

\begin{tabular}{|c|c|}
\hline Job Dimension & Question \\
\hline \multirow[t]{6}{*}{ Product knowledge } & An understanding of product features of competing brands \\
\hline & An understanding of car functionality and manoeuvrability \\
\hline & Ability to accurately identify customer levels \\
\hline & Familiarity with product names \\
\hline & Ability to estimate the prices affordable by customers \\
\hline & Ability to instruct customers how to accurately use products \\
\hline \multirow[t]{7}{*}{ Sales techniques } & Ability to listen to customers' needs and strive to satisfy such needs \\
\hline & Ability to develop new customers \\
\hline & Ability to entice customers' desire to purchase the products via product introduction \\
\hline & $\begin{array}{l}\text { Ability to analyse the pros and cons of own products and competing products so as to make a } \\
\text { compelling case to persuade customers }\end{array}$ \\
\hline & Ability to classify customers in order to plan for efforts required to win business \\
\hline & Ability to accurately and swiftly deal with customers' concerns and complaints \\
\hline & Ability to prioritize tasks in order to maximize service efficiency \\
\hline \multirow[t]{6}{*}{ Interpersonal skills } & Ability to resolve conflicts and establish consensus with communication skills \\
\hline & Ability to effectively communicate and enable others to listen to their own ideas or opinions \\
\hline & Ability to negotiate and persuade customers into immediate purchase \\
\hline & Ability to lead a group or a team to achieve organizational goals \\
\hline & Willingness to share or exchange resources and opinions with others \\
\hline & Ability to establish good cooperative relations with others \\
\hline
\end{tabular}

\section{- Implicit Competences}

Implicit competences include drive for achievements, determination, proactive-ness, ambition, aspiration or desire for money. This paper refers to achievement orientation as a proxy for implicit competences. The survey is based on the measurement for individual's achievement orientation and motivation produced by Yildirim (2007). This section contains a total of 10 questions, shown in Table 2.

Table 2. Questionnaire for implicit competences

\begin{tabular}{ll} 
Job Dimension & Question \\
\hline $\begin{array}{l}\text { Implicit } \\
\text { Competences }\end{array}$ & I give my best to what I think I should be doing, no matter how difficult it is. \\
\cline { 2 - 2 } & I do my best at work until I am pleased with the results. \\
\hline I always wonder whether my current performance has reached my own expectations or \\
standards.
\end{tabular}


- Sales Performance

This paper focuses on auto sales persons, whose performances are in practice reviewed on a yearly basis. Therefore, sales performances are measured with the number of cars sold each year.

- Control Variables

There are inevitable variances in sales performances among salespeople who work in different geographies and for different brands or businesses of varying scales. Therefore, this paper controls the variables such as sex, age, tenure, annual sales, education, location and job title in the empirical process, in order to validate the real relationship between job competences and sales performances.

\subsection{Reliability and Validity}

This paper uses Cronbach's $\alpha$ reliability coefficient to quantity the reliability of the variables in the measurement. Wortzel (1979) believes that a Cronbach's $\alpha$ coefficient of $0.7 \sim 0.98$ indicates high reliability of the sample. Nunally (1978) also suggests that a Cronbach's $\alpha$ of above 0.7 is indicative of high reliability and a coefficient of below 0.35 means the measurement should not be used. The Cronbach's $\alpha$ coefficients for the research variables in this paper are 0.85 for product knowledge, 0.87 for sales techniques, 0.87 for interpersonal skills and 0.80 for implicit competences. Table 3 summarizes the variable reliability of different variables in this paper. Meanwhile, this paper believes that the research variables are valid because the questions are all sourced from literature.

Table 3. Research variable reliability

\begin{tabular}{lcc}
\hline \multicolumn{1}{c}{ Variable } & No. of Questions & Cronbach's $\alpha$ \\
\hline Product knowledge & 6 & 0.8536 \\
Sales techniques & 7 & 0.8731 \\
Interpersonal skills & 6 & 0.8708 \\
Implicit competences & 10 & 0.8013 \\
\hline
\end{tabular}

\subsection{Research Sample}

This paper samples the salespeople working for the top five auto brands in Taiwan, i.e. Nissan, Toyota, Honda, Ford and Mitsubishi. Due to demanding nature of their work, not many salespeople were willing to participate in the survey. Therefore, convenience sampling was conducted on the auto dealers in the northern, central, southern and eastern Taiwan. A total of 500 questionnaires were issued and 308 were recovered, at a recovery rate of $61.6 \%$. After the elimination of 85 invalid questionnaires, this paper collected 223 valid questionnaires, at an effective recovery rate of $44.6 \%$. Table 4 summarizes the distribution of the sample.

Table 4. Questionnaire recovery

\begin{tabular}{cccccc}
\hline \hline Issued & Recovered & Recovery rate & Invalid & $\begin{array}{c}\text { Recovered } \\
\text { valid }\end{array}$ & $\begin{array}{c}\text { Effective } \\
\text { recovery rate }\end{array}$ \\
\hline 500 copies & 308 copies & $61.6 \%$ & 85 copies & 223 copies & $44.6 \%$ \\
\hline \hline
\end{tabular}

\section{Analysis and Discussion}

\subsection{Means, Standard Deviations and Correlation}

Tables 5 6 present the means, standard deviations, maximum values and minimum values of individual variables, as well as correlations between variables. 
Table 5. Means and standard deviations

\begin{tabular}{lllll}
\hline Variable & Mean & $\begin{array}{l}\text { Standard } \\
\text { Deviations }\end{array}$ & $\begin{array}{l}\text { Minimum } \\
\text { Value }\end{array}$ & $\begin{array}{l}\text { Maximum } \\
\text { Value }\end{array}$ \\
\hline 1. Age & 34.19 & 6.76 & 20 & 59 \\
2. Tenure & 6.56 & 5.44 & 1 & 22 \\
3. No. of cars sold p.a. & 41.07 & 36.71 & 0 & 300 \\
4. Product knowledge & 4.14 & 0.29 & 3.50 & 4.67 \\
5. Sales techniques & 4.20 & 0.25 & 3.57 & 4.71 \\
6. Interpersonal skills & 4.13 & 0.29 & 3.50 & 4.67 \\
7. Implicit competences & 4.16 & 0.30 & 3.60 & 4.67 \\
\hline
\end{tabular}

Note: $\mathrm{N}=223 ; * \mathrm{p}<.10 ; \quad * * \mathrm{p}<.05 ; \quad * * * \mathrm{p}<.01$

The coefficient matrix in Table 6 shows the relationships between variables. In general, the correlation coefficients between independent variables, dependent variables and moderating variables are all statistically significant, except the coefficient between sales techniques, interpersonal skills, implicit competences and age, the coefficient between interpersonal skills, implicit competences and tenure, the coefficient between sales techniques, implicit competences and sales performances. The correlation analysis in Table 6 suggests a significant and positive correlation between independent variables such as product knowledge, sales technique and interpersonal skills and moderating variable implicit competences and dependent variable sales performances. The absolute values of all the three coefficients are all below 0.65 , consistent with the 0.65 standard value recommended by Thomas and Williams (1991). These numbers indicate the independence of variables and less likely collinearity between variables.

Table 6. Correlations coefficient matrix between variables

\begin{tabular}{|c|c|c|c|c|c|c|c|}
\hline Research Variables & 1. & 2. & 3. & 4. & 5. & 6. & 7. \\
\hline 1. Age & 1 & & & & & & \\
\hline 2. Tenure & $0.679 * *$ & 1 & & & & & \\
\hline 3. No. of cars sold p.a. & $0291 * *$ & $0.312 * * *$ & 1 & & & & \\
\hline 4. Product nowledge & $0.135^{*}$ & $0.143 *$ & $0.275 * * *$ & 1 & & & \\
\hline 5. Sales techniques & 0.081 & $0.156^{*}$ & 0.108 & $0.299 * * *$ & 1 & & \\
\hline 6. Interpersonal skills & 0.132 & 0.106 & $0.179 * *$ & $0.213 * * *$ & $0.475 * * *$ & 1 & \\
\hline 7.Implicit competences & 0.086 & 0.128 & 0.034 & $0.352 * * *$ & $0.414 * * *$ & $0.365^{* * *}$ & 1 \\
\hline
\end{tabular}

Note: $\mathrm{N}=223 ; \quad{ }^{*} \mathrm{p}<.10,{ }^{* *} \mathrm{p}<.05,{ }^{* * *} \mathrm{p}<.01$

\subsection{Effects of Control Variables on Sales Performances}

According to Model 1 in Table 7, the Toyota salespeople post better results compared to Mitsubishi $(\beta=0.230$, $\mathrm{P}<0.05$ ). However, the difference is not statistically significant if compared with Nissan, Honda or Ford. The regression results in this study suggest that females (as benchmark) post better sales than males $(\beta=-0.149, \mathrm{P}<0.1)$. Also, the older the salespeople, the better sales they generate $(\beta=0.183, \mathrm{P}<0.1)$. Sales directors (benchmark) create higher revenues compared to sales representatives $(\beta=-0.212, \mathrm{P}<0.1)$. Salespeople in northern Taiwan (benchmark) are the top performers, followed by their peers in central Taiwan $(\beta=-0.147, \mathrm{P}<0.05)$ and in southern Taiwan $(\beta=-0.2$, $\mathrm{P}<0.1)$. However, there is no significant correlation for salespeople in eastern Taiwan. Other variables such as tenure and education do not show statistical significance with sales performances. 
Table 7. Regression analysis on effects of explicit/implicit competences on sales performances

\begin{tabular}{|c|c|c|c|c|c|}
\hline Variable & Model1 & Model2 & Model3 & Model4 & Model5 \\
\hline Constant & $2.463^{* *}$ & $2.872 * *$ & $3.148 * * *$ & $3.526 * * *$ & $3.815 * * *$ \\
\hline \multicolumn{6}{|l|}{ MITSUBISHI (benchmark) } \\
\hline FORD & -0.049 & -0.051 & -0.052 & -0.048 & -0.054 \\
\hline TOYOTA & $0.230 * *$ & $0.215^{* *}$ & $0.231 * *$ & $0.215^{* *}$ & $0.215^{* * *}$ \\
\hline HONDA & -0.039 & -0.052 & -0.040 & -0.052 & -0.046 \\
\hline NISSAN & -0.035 & -0.053 & -0.031 & -0.055 & -0.057 \\
\hline Female (benchmark) & Benchmark & Benchmak & Benchmar & Benchmark & Benchmark \\
\hline Male & $-0.149^{*}$ & $-0.14 *$ & $-0.150 *$ & $-0.147^{*}$ & -0.135 \\
\hline Age & $0.183^{*}$ & 0.156 & 0.183 & 0.155 & 0.143 \\
\hline Tenure & 0.134 & 0.112 & 0.136 & 0.124 & 0.142 \\
\hline $\begin{array}{l}\text { Below high school } \\
\text { (benchmark) }\end{array}$ & Benchmark & Benchmark & Benchmark & Benchmark & Benchmark \\
\hline \multicolumn{6}{|l|}{ Education } \\
\hline College & 0.053 & 0.038 & 0.053 & 0.041 & 0.045 \\
\hline University & -0.057 & -0.053 & -0.057 & -0.042 & -0.040 \\
\hline \multicolumn{6}{|l|}{ Geography } \\
\hline North (benchmark) & Benchmark & Benchmark & Benchmark & Benchmark & Benchmark \\
\hline Central & $-0.147 *$ & $-0.146^{*}$ & $-0.147^{*}$ & $-0.146^{*}$ & $-0.141^{*}$ \\
\hline South & $-0.2 * *$ & $-0.216^{* * *}$ & $-0.199 * *$ & $-0.215^{* * *}$ & $-0.212 * *$ \\
\hline East & -0.34 & -0.014 & -0.035 & -0.020 & -0.019 \\
\hline \multicolumn{6}{|l|}{ Title } \\
\hline $\begin{array}{l}\text { Sales Director } \\
\text { (benchmark) }\end{array}$ & Benchmark & Benchmark & Benchmark & Benchmark & Benchmark \\
\hline Specialist & -0.082 & -0.105 & -0.082 & -0.099 & -0.104 \\
\hline Representative & $-0.212 *$ & $-0.209 *$ & $-0.211^{*}$ & $-0.202 *$ & $-0.211^{*}$ \\
\hline \multicolumn{6}{|l|}{ Explicit Competence } \\
\hline Product knowledge & & $0.201 * * *$ & & $0.266 * * *$ & $1.482 * *$ \\
\hline Sales techniques & & -0.003 & & 0.031 & $1.854 * * *$ \\
\hline Interpersonal skills & & $0.092 * *$ & & $0.101 * *$ & $1.204 * *$ \\
\hline Implicit Competence & & & -0.063 & $-0.194 * * *$ & $3.821 * * *$ \\
\hline $\begin{array}{l}\text { Implicit Competence } \\
\times \text { Product knowledge }\end{array}$ & & & & & $1.971^{* *}$ \\
\hline $\begin{array}{l}\text { Implicit Competence } \\
\times \text { Sales techniques }\end{array}$ & & & & & $3.035 * * *$ \\
\hline $\begin{array}{l}\text { Implicit Competence } \\
\quad \times \text { Interpersonal skills }\end{array}$ & & & & & $1.640 *$ \\
\hline Adjusted $\mathrm{R}^{2}$ & 0.165 & 0.210 & 0.160 & 0.219 & 0.209 \\
\hline
\end{tabular}

Note: a. $\mathrm{N}=223 ;{ }^{*} \mathrm{p}<.10 ;{ }^{* *} \mathrm{p}<.05 ;{ }^{* \pi *} \mathrm{p}<.01$ (2-tailed)

\subsection{Effects of Explicit Competences on Sales Performances}

According to Model 2 in Table 7, there is a positive and significant correlation between product knowledge and sales performances $(\beta=0.201, \mathrm{P}<0.01)$, supporting H1a. Sales techniques are not significantly correlated with sales performances, not supporting H1b. Although sales techniques are important, they do not seem to be the most critical factor in closing deals. The use of sales techniques does not generally win trust from customers or lead to sales. The research shows a positive and significant correlation between interpersonal skills and sales performances $(\beta=0.092$, $\mathrm{P}<0.5$ ), supporting H1c. 


\subsection{Effects of Implicit Competences on Sales Performances}

According to Model 3 in Table 7, there is no significant correlation between implicit competences and sales performances, rejecting H2. Strong ambitions and implicit competences alone do not seem to help generate sales. This paper argues that a strong drive without implementation skills does not help to create good numbers. Fresh graduates are often keen to give their best shot, particularly those who choose sales as a career. New to the auto industry, they are not equipped with good product knowledge, sales techniques or interpersonal networks. As a result, their ambitions tend to fall short of expectations and their sales results are far from satisfactory.

\subsection{Effects of Explicit/Implicit Competences on Sales Performances}

Model 4 in Table 7 refers to explicit competences (i.e. product knowledge, sales techniques and interpersonal skills) as independent variables, implicit competences as a moderating variable and sales performances as a dependent variable. The purpose is to explore the interactive effects of explicit competences (i.e. product knowledge, sales techniques and interpersonal skills) and implicit competences on sales performances.

\section{- Combined Effects of Explicit Competences and Implicit Competences on Sales Performances}

Model 4 in Table 7 validate the combined effects of the three explicit competences (i.e. product knowledge, sales techniques and interpersonal skills) and implicit competences on sales performances of auto salespeople. The empirical results indicate that the directional impact of product knowledge and implicit competences to sales performances $(\beta=0.266, \mathrm{P}<0.01)$ and the directional impact of interpersonal skills and implicit competences to sales performances $(\beta=101, \mathrm{P}<0.05)$. Both results are consistent with the findings in Model 2.

\section{- Interactive Effects of Explicit Competences and Implicit Competences on Sales Performances}

Model 5 in Table 7 validate the interactive effects of explicit competences and implicit competences on sales performances. The results suggest positive and positive interactive effects of implicit competences on product knowledge $(\beta=1.971, \mathrm{P}<0.05)$, on sales techniques $(\beta=3.035, \mathrm{P}<0.01)$ and on interpersonal skills $(\beta=1.640, \mathrm{P}<0.1)$, supporting $\mathrm{H} 3 \mathrm{a}, \mathrm{H} 3 \mathrm{~b}$ and $\mathrm{H} 3 \mathrm{c}$.

\section{Conclusions and Managerial Implications}

\subsection{Conclusions}

Competences are a combination of knowledge, skillsets, behavior and attitude. They can improve work performances, boost firm competitiveness and augment the influence of a business on an economy. Salespeople are tasked to sell the products or services for their companies. They have to convince novice customers into purchasing and persuade existing customers into repeated sales by maintaining their levels of satisfaction. Given the ongoing frustrations and pressures of the process, it is hardly surprising that only salespeople equipped with both explicit and implicit competences are able to make the cut.

This paper seeks to verify the direct effects of explicit competences and implicit competences on the sales performances of the auto salespeople, as well as the moderating role of implicit competences on the effect of explicit competences on sales performances. The empirical results are as follows: (1) the better the product knowledge and interpersonal skills, the better the sales performances; (2) implicit competences and sales techniques have no direct impact on sales performances; (3) the implicit competences strength product knowledge and interpersonal skills and hence sales performances. However, sales techniques have no such impact.

\subsection{Management Implications}

- Product knowledge and interpersonal skills have more pronounced effects on performance of salespeople than sales techniques

Salespeople only aiming to close the deal are unlikely to gain trust from customers. It is prerequisite that salespeople understand the products, listen carefully to customers for their requirements and think on behalf of their customers. The ability to convey key messages and provide professional advice in a timely and humorous manner is the first step to the trust of customers. Salespeople only good at sales techniques often focus on the transactions and are less likely to win the trust of customers. This paper finds that the impact of product knowledge and interpersonal skills is more pronounced than the impact of sales techniques on the job performance of sales people.

- Implicit competences of salespeople have no direct effects on their sale performance but such competences reinforce the impact of product knowledge and interpersonal skills on sale performance

Implicit competences refer to self-identity, personal traits and motivations. They are part of the attitude. This paper argues that attitudes alone are insufficient. Actions are the key to sales improvement. In fact, salespeople should have 
first-hand experience in the functionality and value of the products they sell. Salespeople have to manage customer relationships to generate a steady stream of business leads. Implicit competences have no direct impact on sales results, but augment the relationship between product knowledge, interpersonal skills and sales performances. In other words, explicit competences play a pivotal role and implicit competences play a supporting role in the sales process.

\section{References}

Andrew, N. G., \& Johnson, M. P. (2006). Leadership competencies: An Introduction. Journal of Healthcare Management, 51(1), 13-18.

Arthey, T. R., \& Orth M. S. (1999). Emerging competency methods for the future. Human Resource Management, 38(3), 215-225. http://dx.doi.org/10.1002/(SICI)1099-050X(199923)38:3<215::AID-HRM4>3.0.CO;2-W

Becker, B., Huselid, M., \& Ulirch, D. (2001). The HR Scorecard: Linking People, Strategy, and Performance. Boston, MA: Harvard Business School Press.

Blank, I. (2008). Selecting employees based on emotional Intelligence competencies: reap the rewards and minimize the risk. Employee Relations Law Journal, 34(3), 77-85.

Broeck, A. V. D., Vansteenkiste, M., Witte, H. D., Soenens, B., \& Lens, W. (2010). Capturing autonomy, competence, and relatedness at work: Construction and initial validation of the Work-related Basic Need Satisfaction scale. Journal of Occupational and Organizational Psychology, 83, 981-1002. http://dx.doi.org/10.1348/096317909X481382

Churchill, G. A., Ford, N. M., Hartely, S. W., \& Walker, O. C. (1985). The determinants of salesperson performance: a meta-analysis, Journal of Marketing Research, 22(2), 103-118. http://dx.doi.org/10.2307/3151357

Cofsky, K. M. (1993). Critical keys to competency-based pay, Compensation and Benefits Review, 25(6), 45-52. http://dx.doi.org/10.1177/088636879302500609

De Houwer, J. (2006). What are implicit measures and why are we using them. In R. W. Wiers and A. W. Stacy (Eds.), The handbook of implicit cognition and addiction (pp. 11-28). Thousand Oaks, CA: Sage Publishers. http://dx.doi.org/10.4135/9781412976237.n2

Draganidis, F., \& Mentzas, G. (2006). Competency based management a review of systems of approaches. Information Management and Computer Security, 14(1), 51-64. http://dx.doi.org/10.1108/09685220610648373

Dubois, D. D., Rothwell, W. J., Stern, D. J., \& Kemp, L. K. (2004). Competency-Based Human Resource Management. Palo Alto, CA: Davies-Black.

Erika, R. (1999). The 10 Traits of top Salespeople, Sales and Marketing Management, 5(8), 34-37.

Gendolla, G. H. E. (2006). Static thinking as cognitive coping with performance difficulties: The role of motivation and arousal. Anxiety Stress and Coping, 19(3), 293-307. http://dx.doi.org/10.1080/10615800600841265

Heilmann, P. (2011). The dialectics between boundaryless career and competence development - Findings among finnish ICT and paper managers. The International Journal of Human Resource Management, 22(1), 181-196. http://dx.doi.org/10.1080/09585192.2011.538981

Howland, R. H. (1978). Programmed Learning Aid for Principles of Salesmanship. Homewood Ill: Dow Jones-Irwin.

Kim, S., \& Hong, J. (2005). The relationship between salesperson competencies and performance in Korean pharmaceutical industry. Management Revue, 16(2), 259-268.

Levenson, A. R., Vander Stede, W. A., \& Cohen, S. G. (2006). Measuring the relationship between managerial competencies and performance. Journal of Management, 32(3), 360-380. http://dx.doi.org/10.1177/0149206305280789

Mayer, J. P. (2003). Are the public health workforce competencies predictive of essential service performance? a test at a large metropolitan local health department. Journal of Public Health Management and Practice, 9(3), 208-213. http://dx.doi.org/10.1097/00124784-200305000-00005

Milkovich, T. G., \& Newman, M. J. (1999). Compensation. New York: McGraw-Hill.

Mirabile, R. J. (1997). Everything you wanted to know about competency modeling. Training and Development, 51(8), 73-77. 
Nosek, B. A. (2007). Implicit-explicit relations. Current Directions in Psychological Science, 16, 65-69. http://dx.doi.org/10.1111/j.1467-8721.2007.00477.x

Nosek, B. A., \& Smyth, F. L. (2007). A multitrait-multimethod validation of the Implicit Association Test: Implicit and explicit attitudes are related but distinct constructs. Experimental Psychology, 54(1), 14-29. http://dx.doi.org/10.1027/1618-3169.54.1.14

Nunally, J. C. (1978). Psychometric Theory (2nd ed.). New York: MacGraw-Hill.

Peterson, C. A., Wright, M. D., \& Weitz, B. A. (1984). Selling: Principle and Methods, Homewood, I11: Irwin.

Schermerhorn, J. R. (1989). Management for productivity (3rd ed.). New York: Wiley and Sons.

Seal, C., Boyatzis, R., \& Bailey, J. (2006). Fostering emotional and social intelligence in organizations. Organization Management Journal, 3(3), 190-209. http://dx.doi.org/10.1057/omj.2006.19

Shaw, D. M. (2007). Building sales competences through service learning. Marketing Education Review, 17(1), $35-41$.

Soderquist, K., Papalexandris, A., Ioannou, G., \& Prastacos, G. (2010). From task-based to competency-based: A typology and process supporting a critical HRM transition. Personnel Review, 39(3), 325-346. http://dx.doi.org/10.1108/00483481011030520

Spencer, L. M., \& Spencer, S. M. (1993). Competence at Work: Models for Superior Performance. New York: John Wiley and Sons.

Thomas, A., \& Williams, G. R. (1991, October). A strategy to provide retirement benefits for international transferees in a global company. Benefits and Compensation International, 2-7.

Ulrich, D., Brockbank, W., Yeung, A. K., \& Lake, D. G. (1995). Human resource competencies: an empirical assessment. Human Resource Management, 34(4), 473-495. http://dx.doi.org/10.1002/hrm.3930340402

Vazirani, N. (2010, April - August). Review Paper: Competencies and Competency Model-A brief overview of its Development and Application. SIES Journal of Management, 7(1), 121-131.

Wei, L. Q., \& Lau, C M. (2005). Market orientation, HRM importance and competency: determinants of strategic HRM in Chinese firms. Journal of Human Resource Management, 16(10), 1901-1918. http://dx.doi.org/10.1080/09585190500298586

Wortzel, R. (1979). New life style determinants of women's food shopping behavior. Journal of Marketing, 43(1), 28-29.

Yildirim, O. (2007). Discriminating emotional intelligence-based competencies of IT employees and salespeople. Journal of European Industrial Training, 31(4), 274-282. http://dx.doi.org/10.1108/03090590710746432 